\title{
IMPLEMENTASI UNDANG-UNDANG NOMOR 06 TAHUN 20 I 4 PASAL 55 TENTANG FUNGSI BADAN PERMUSYAWARATAN DESA DALAM LINGKUP KECAMATAN SIRITAUN WIDA TIMUR KABUPATEN SERAM BAGIAN TIMUR
}

\author{
Implementation Of Law Number 06 Of 2014 Article 55 Concerning the Functions of Village \\ Consultative Bodies in the Scope of Siritaun Wida Timur District, East Seram Regency
}

\section{Kisman Ady \\ Nunung Triyani}

Universitas Darussalam Ambon, Ambon, Maluku, Indonesia

Email : kismanady@yahoo.com

\section{Keywords :}

Implementation

Village Regulations

Aspirations

Supervision

Kata Kunci :

Implementasi

Peraturan Desa

Aspirasi

Pengawasan

Published

October 2020

\begin{abstract}
Abstrak
Penelitian ini dilakukan di 10 desa yang tergolong dalam Kecamatan Siritaun Wida Timur Kabupaten Seram Bagian Timur yaitu tentang implementasi undang-undang nomor 06 tahun 2014 pasal 55 tentang fungsi Badan Permusyawaratan Desa dengan menggunakan metode deskriptif kualitatif. Sumber data yang digunakan adalah data primer berupa hasil observasi dan wawancara yang berasal dari semua anggota Badan Permusyawaratan Desa. Teknik pengumpulan data adalah wawancara mendalam terhadapat seluruh informan dan observasi dilakukan untuk mengumpulkan data dengan cara mengamati setiap proses dari implementasi yang dilakukan. Hasil penelitian menunjukkan bahwa implementasi fungsi yang dilakukan oleh Badan Permusyawaratan Desa se-Kecamatan Siritaun Wida Timur telah terlaksana yaitu fungsi menampung dan menyalurkan aspirasi masyarakat desa dan pengawasan terhadap kinerja Kepala Desa namun implementasinya juga belum terlalu maksimal, sedangkan fungsi membahas dan menyepakati peraturan desa bersama Kepala Desa belum dilakukan.
\end{abstract}

\begin{abstract}
This research was conducted in 10 villages belonging to the Siritaun Wida Timur Subdistrict, East Seram Regency, which is about the implementation of law number 06 of 2014 article 55 concerning the function of the Village Consultative Body using qualitative descriptive methods. The data source used is primary data in the form of observations and interviews from all members of the Village Consultative Body. The data collection technique is in-depth interviews with all informants and observations are made to collect data by observing each process of the implementation carried out. The results showed that the implementation of the functions carried out by the Village Consultative Body in the Siritaun Wida Timur District has been carried out, namely the function of accommodating and channeling the aspirations of the village community and monitoring the performance of the Village Head, but the implementation has not been too optimal, while the function of discussing and agreeing on village regulations with the Head Village has not been done.
\end{abstract}

\section{PENDAHULUAN}

Implementasi kebijakan merupakan tahap yang krusial dalam proses kebijakan publik. Suatu program kebijakan harus diimplementasikan agar mempunyai dampak atau tujuan yang diinginkan mengingat tanpa tahap implementasi kebijakan maka program-program kebijakan yang telah disusun hanya akan menjadi catatan-catatan resmi di meja para pembuat kebijakan. Dalam kenyataannya, tahapan implementasi menjadi begitu penting karena suatu kebijakan tidak akan berarti apa-apa jika tidak dapat dilaksanakan dengan baik dan benar. Dengan demikian maka implementasi merupakan tahap dimana suatu kebijakan publik dilaksanakan secara maksimal oleh implementator- implementator/ pelaksana untuk dapat mencapai tujuan kebijakan itu sendiri.

Untuk memajukan desa-desa yang tertinggal dalam Negara Kesatuan Republik Indonesia, maka diterbitlah undang-undang nomor 06 tahun 2014 yang mengatur tentang desa. Publik telah mengetahui bahwa 
keseluruhan desa-desa tertinggal telah diberlakukn undang-undang yang mengatur tentang desa tersebut, namun pengukuran implementasi dari undang-undang itu masih berada jauh dari harapan yang diinginkan.

Beranjak dari uraian tersebut sama halnya dengan implementasi undang-undang nomor 06 tahun 2014 pasal 55 tentang fungsi Badan Permusyawaratan Desa, bahwa implementasi menyangkut pasal 55 tersebut yang telah dijalankan oleh Badan Permusyawaratan Desa se-Kecamatan Siritaun Wida Timur terindikasi memiliki nilai yang jauh dari pada harapan dan tuntutan pasal 55 undang-undang nomor 06 tahun 2014. Indikasi yang membuat nilai dari Badan Permusyawaratan Desa yang tergolong dalam Kecamatan Siritaun Wida Timur itu menurun adalah I). Tidak adanya pembahasan peraturan desa antara Badan Permusyawaratan Desa dengan Pemerintah Desa setempat, 2). Badan Permusyawaratan Desa tidak menggunakan fungsinya secara baik untuk meminta dan/atau menampung aspirasi masyarakat desa, sehingga program-program desa hanya mengikuti kemauan Pemerintah Desa. 3). Tidak ada pengawasan yang baik dari Badan Permusyawaratan Desa kepada Pemerintah Desa menyangkut dengan keseluruhan kinerja Pemerintah Desa.

Dengan demikian penelitian ini bertujuan untuk mengetahui peran Badan Permusyawaratan Desa dalam mengimplementasikan fungsinya yaitu membahas dan menyepakati peraturan desa bersama Kepala Desa, menampung dan menyalurkan aspirasi masyarakat desa, dan melakukan pengawasan kinerja Kepala Desa.

Istilah kebijakan publik dalam kehidupan sehari-hari sering digunakan untuk menunjuk suatu kegiatan yang mempunyai maksud berbeda, sehingga para ahli dapat mengembangkan berbagai macam definisi untuk menjelaskan apa yang dimaksud dengan kebijakan publik. Untuk itu masing-masing definisi memberi penekanan yang berbeda. Contoh seperti menurut Thomas R. Tye dalam Elake Nataniel (2015:39) mengatakan dengan secara sederhana bahwa kebijakan publik adalah apapun yang dipilih oleh pemerintah untuk dilakukan atau tidak dilakukan. Pendapat ini menunjukkan bahwa kebijakan yang berupa apapun yang dipilih pemerintah adalah merupakan pilihan yang tepat yang akan dilakukan atau tidak, namun pada harapannya yaitu harus dilakukan demi untuk kepentingan publik. Maksud demi kepentingan publik itu seperti pendapat menurut H. Budiman Rusli (2013:9) kebijakan publik adalah alat untuk mencapai tujuan publik, bukan tujuan orang perorang atau golongan dan kelompok. Meskipun sebagai alat (tool) keberadaan kebijakan publik sangat penting dan sekaligus krusial. Penting karena keberadaannya sangat menentukan tercapainya sebuah tujuan, meskipun masih ada sejumlah prasyarat atau tahapan lain yang harus dipenuhi sebelum sampai pada tujuan yang dikehendaki.

Dari berbagai kepustakaan, dapat diungkapkan bahwa kebijakan publik dalam kepustakaan internasional disebut sebagai public policy, yaitu suatu aturan yang mengatur kehidupan bersama yang harus ditaati dan berlaku mengikat seluruh warganya. Setiap pelanggaran akan diberi sanksi sesuai dengan bobot pelanggarannya yang dijatuhkan di depan masyarakat oleh lembaga yang mempunyai tugas menjatuhkan sangsi. (Nugroho R, dalam Uddin B.Sore dan Sobirin 2017:8) Aturan atau peraturan tersebut secara sederhana kita pahami sebagai kebijakan publik jadi kebijakan publik ini dapat kita artikan sebagai suatu hukum. Tidak hanya sekedar hukum, tetapi kita harus memahaminya secara utuh dan benar. Dalam hal ini kebijakan dapat dimaknai berupa suatu deklarasi mengenai suatu dasar pedoman bertindak, suatu arah tindakan tertentu, suatu program mengenai aktivitas-atktivias tertentu atau suatu rencana. (united nations dalam Rahmat Alyakin Dachi, 2017:4).

Diterbitkanlah suatu kebijaka yang diatur dengan undang-undang nomor 06 tahun 2014 tentang desa, mengatur seluruh hal ihwalnya suatu desa dapat dijadikan pedoman untuk membangun desa pada posisi yang lebih baik, dikarenakan kabijakan publik yang mengatur tentang desa merupakan tindakan yang dibuat 
dan dilaksanakan oleh pemerintah yang dampaknya menjangkau atau dirasakan oleh seluruh lapisan masyarakat. Dengan demikian kebijakan publik merupakan langka penyelamatan bagi seluruh elemen masyarakat tentang sesuatu hal, mengingat kebijakan publik adalah kaitannya dengan kehidupan umum. Seperti menurut Mr. Sugiono dalam Taufiqurokhmat (20।4:49) kebijakan publik adalah usaha bersama dari warga masyarakat untuk membagi resources yang ada di dalam masyarakat secara damai dan adil serta sifatnya yang mengikat.

Implementasi kebijakan merupakan tahapan pelaksanaan keputusan diantara pembentukan sebuah kebijakan, seperti halnya pasal-pasal sebuah undangundang legislatif, keluarnya sebuah peraturan eksekutif, dan lain-lain. Jika sebuah kebijakan diambil secara tepat, maka kemungkinan kegagalan masi bisa terjadi, jika proses implementasinya secara tidak baik dan optimal, maka kebijakan tersebut gagal untuk mencapai tujuan yang ditetapkan para pembuatnya. $\mathrm{Hal}$ tersebut mengisyaratkan bahwa implementasi kebijakan pada substansinya adalah cara yang tepat untuk melaksanakan agar sebuah kebijakan yang baik dapat mencapai tujuan sebagaimana yang telah ditetapkan oleh para pembuat kebijakan. Untuk lebih mengimplementasikan kebijakan publik, Nugroho dalam Arifin Tahir (2015:54) menawarkan dua pilihan langkah yaitu: "lansung mengimplementasikan dalam bentuk program-program, dan melalui formulasi kebijakan derivate atau turunan dari kebijakan publik tersebut”. Dari dua pilihan tersebut, agar setiap kebijakan dapat diimplementasikan, maka seharusnya pula memperhatikan apa dan bagaimana bentuk program yang realitas, sehingga dapat memenuhi kepentingan publik.

Sementara itu Abdul Wahab dalam Arifin Tahir (20I5:55) juga mengatakan bahwa implementasi kebijakan adalah pelaksanaan keputusan kebijakan dasar, biasanya daam bentuk undang-undang, namun dapat juga berbentuk perintah-perintah atau keputusan-keputusan eksekutif yang penting atau keputusan badan peradilan lazimnya keputusan tersebut mengidentifikasikan masalah yang diatasi, menyebutkan secara tegas tujuan/sasaran yang ingin dicapai dan berbagai cara untuk menstruktur/ mengatur proses implementasinya.

Bertolak dari uraian diatas, berarti implementasi merupakan tolak ukur dari berhasilnya suatu kebijakan dan untuk itu implementasi ini bagaikan kunci keberhasilan dari kebijakan itu sendiri walaupun sering ditemukan kekurangan-kekurangan dalam implementasi. Hal tersebut juga disampaikan oleh Arifin Tahir dalam bukunya bahwa implementasi diartikan sebagai upaya melakukan, mencapai, memenuhi, dan menghasilkan. Dalam berbagai praktek terlihat bahwa suatu keputusan telah ditetapkan tidak selalu dilaksanakan dengan tertib dan rapi. Seandainya suatu rencana keputusan yang terdiri seperangkat tujuan/sasaran, sarana, dan waktu yang dipilih dan ditetapkan dalam implementasinya, banyak terjadi bahwa keputusan tersebut hampir selalu harus disesuaikan lagi. Misalnya, karena perumuan tujuan terlalu umum, sarana tidak dapat diperoleh atau tidak dapat dipakai tepat pada waktunya. Atau karena faktor waktu yang dipilih terlalu optimistik dan sebagainya, hal ini merupakan gambaran yang kurang tepat pada implementasi keputusan. (Arifin Tahir 2015:56).

Penjelasan menyangkut implementasi tersebut diuaraikan juga oleh Van Meter dan Van Horn yang dikutip oleh Wahab dalam Sahya Aggara (20|4:232) implementasi adalah tindakan-tindakan yang dilakukan oleh individu/pejabat atau kelompok pemerintah atau swasta yang diarahkan pada tercapainya tujuan yang telah digariskan dalam keputusan kebijakan. Sehubungan dengan itu, hakikat utama implementasi kebijakan menurut Mazmanian dan Sabatir dalam Sahya Aggara (2014:232) adalah memahami hal-hal yang seharusnya terjadi setelah suatu program dinyatakan berlaku atau dirumuskan. Pemahaman tersebut mencakup usahausaha untuk mengadministrasikannya dan menimbulkan dampak nyata pada masyarakat. 
Pada tahap implementasi kebijakan maka perlunya memperoleh dukungan sumberdaya, dan penyusunan organisasi pelaksana kebijakan. Untuk menjawab keberhasilan dari suatu kebijakan yang berkualitas maka salah satu kunci utama dari pengelolaan kebijakan yang berkualitas tersebut adalah tingginya implementasi partisipasi publik, sebab kesahihan kebijakan publik apapun dari pemerintah terletak disana. Menurut Marille S. Grindle dalam syaukani yang dikutip oleh Fahmi Rijal (2016:3-4) mengidentifikasikan dua hal yang sangat menentukan keberhasilan dari implementasi yang secara terperinci sebagai berikut:

a. Isi kebijakan (content of policy):

(I). Kepentingan siapa saja yang terlihat (interests affected). (2). Macam-macam manfaat (type of benefits). (3). Sejauh mana perubahan akan diwujudkan (extent of change envisioned). (4). Tempat pembuatan kebijakan (site of decision making) (5). Sumberdaya yang disediakn (resources commited)

b. Konteks dari implementasi (context of implementation):

(I). Kekuasaan, kepentingan, dan strategi para aktor yang terlibat (power, interest, and strategy of actors involved). (2). Karakteristik lembaga dan rejim (institutions and regime characteristics). (3). Sesuai dengn kaida dan tingkat responsive (compliance and responsiveness).

\section{METODE PENELITIAN}

Penelitian menggunakan metode atau pendekatan deskriptif kualitatif dengan dasar penelitian survei yang memberikan data atau gambaran secara menyeluruh tentang implementasi undang-undang nomor 06 tahun 2014 pasal 55 tentang fungsi Badan Permusyawaratan Desa (BPD) dalam lingkup Kecamatan Siritaun Wida Timur Kabupaten Seram Bagian Timur.
Sumber data yang digunakan adalah data primer dan data sekunder.

I. Data Primer

Data yang bersumber lansung dari seluruh informan yang penulis mengumpulkannya melalui proses wawancara mendalam.

2. Data Sekunder

Data yang bersumber dari berbagai dokumendokumen yang valid berkaitan dengan fokus penelitian, untuk itu data sekunder ini penullis gunakan sebagai pelengkap dari hasil penelitian.

Teknik analisis data yang digunakan adalah data penelitian yang dikumpulkan diproses dalam bentuk yang sederhana, sehingga mudah dibaca dan diinterpretasikan. Proses analisa data dalam penelitian ini dengan menggunakan analisis data kualitatif yakni dengan menghasilkan data apa yang dinyatakan oleh informan secara tertulis serta data yang berasal dari alat perekam dan dokumen yang valid, kemudian dicermati serta dipelajari sebagai sesuatu yang utuh, lalu disajikan sesuai dengan variabel-variabel yang telah dijadikan indikator dari penelitian ini. Penelitian ini meliputi 8 desa sehingga penulis menganalisis masing-masing desa dengan terpisah serta hasilnya, kemudian penulis merangkumnya dengan secara keseluruhan hasil dari masing-masing desa untuk didapatkan satu hasil yang utuh.

\section{HASIL DAN PEMBAHASAN}

a. Membahas dan Menyepakati Rancangan Peraturan Desa Bersama Kepala Desa

Peraturan desa merupakan suatu peraturan perundang-undangan yang dibuat dan ditetapkan oleh kepala pemerintahan desa dan Badan Permusyawaratan Desa atau dapat disebut dengan nama lain. Tujuan dibuatkan peraturan desa untuk menjaga agar semua aktifitas berbagai kalangan di desa dapat terpantau dengan baik. Peraturan desa yang dibuat yakni berlaku hanya untuk desa 
setempat dan peraturan desa dibuat dengan memperhatikan peraturan perundang-undangan yang lebih tinggi serta kondisi sosial budaya setempat kemudian juga tidak bertentangan dengan kepentingan umum.

Dalam proses penelitin yang berkaitan dengan implementasi fungsi Badan Permusyawaratan Desa dari 10 desa yang tergolong dalam lingkup Kecamatan Siritaun Wida Timur Kabupaten Seram Bagian Timur, indikator yang diteliti adalah membahas dan menyepakati rencangan peraturan desa bersama kepala desa. Sesuai dengan hasil peneltian yang telah peneliti uraikan bahwa semua desa dalam lingkup Kecamatan Siritaun Wida Timur tidak mengimplementasikan fungsinya dalam membahas maupun menyepakati peraturan desa bersama kepala desa, beragam indikasi yang menjadi alasan bahwa fungsi tersebut tidak dilakukan adalah dikarenakan:

I. Belum memiliki surat keputusan (SK) yang menjadi bukti hukum yang mengesahkan keanggotaan mereka sebagai Badan Permusyawaratan Desa (BPD), berbeda dengan BPD desa lain yang mengatakan bahwa SK masi berada di tangan Kepala Desa.

Suwatu lembaga/badan yang bertugas menjalankan roda pemerintahan maka harus diperkuat dengan bukti hukum yang sesuai dengan aturan yang berlaku, bukti hukum yang memperkuat keberadaan dalam struktur pemerintahan. Sangat disayangkan jika keberadaan orang-orang dalam suatu lembaga/badan tidak mendapatkan pengesahan. Jika demikian maka tidak akan ada keseriusan dalam menjalakan fungsinya apalagi ditambah dengaan pejabat yang memilih diam maka tentunya masalah ini akan selalu berlarut. BPD atau yang dapat disebut dengan nama lain pada suatu desa adalah sebagai parlemennya desa, ini berarti lembaga perwujudan demokrasi yang harus memiliki surat keputusan yang mengesahkannya. Badan Permusyawaratan Desa merupakan lembaga perwujudan demokrasi dalam penyelenggaraan pemerintahan desa sebagai unsur penyelengara pemerintahan desa.

2. BPD dan pihak pemerintah desa belum berpikir untuk membahas dan menyepakati peraturan desa sehingga hanya menjalankan hal-hal teknis terkait program pemerintah daerah.

Tugas dan fungsi yang melekat pada lembaga pemrintah desa dan BPD telah diatur secara rinci dalam undang-undang nomor 06 tahun 2014, tugas dan fungsi tersebut wajib diimplementasikan secara baik dan teratur menuju keberhasilan pembangunan desa yang menjadi tujuan Negara. Untuk itu alasan yang disampaikan dari pon ini tidak relefa dengan fungsi yang diemban sehingga. Program teknis yang dikeluarkan oleh pemerintah daerah kepada pemerintah desa merupakan bagian dari fungsi BPD untuk mengawasi.

3. Belum ada koordinasi dari pemerintah desa kepada BPD untuk membahas maupun menetapkan peraturan desa.

Tujuan dilakukannya koordinasi antar lembaga atau instansi untuk memperjelas hubungan kerja sama yang baik adalah suatu keharusan yang harus diutamakan. Membahas dan menyepakati peraturan desa merupakan fungsi yang harus dilakukan oleh BPD dan pemerintah desa untuk itu bicara tentang koordinasi dalam konteks ini maka jika koordinasi tidak dilakukan oleh pemerintah desa kepada BPD maka BPD wajib melakukan koordinasi kepada pemerintah desa untuk mendapatkan kepastian dari pengimplementasian fungsi tersebut. Kiranya dari alasan koordinasi yang termuat dalam poin ini adalah pemahaman BPD yang keliru akan fungsi yang diemban. 
4. Belum adanya anggaran pembahasan peraturan desa.

Anggaran merupakan suatu unsur pendukung yang utama dalam sebuah rancangan peraturan desa dengan demikian alasan ini dikatakan relefan untuk diterima jika tidak adanya anggaran yang diprioritaskan kepada desa masing-masing namun kenyataannya pada setiap tahun terdapat anggaran yang terus disodorkan untuk pembangunan desa hanya saja tidak adanya niat baik yang dibangun oleh pemerintah desa dan BPD terkait dengan penetapan angaran pembahasan peraturan desa.

5. Peraturan desa telah dibahas namun belum ditetapkan sebagai peraturan yang sah.

Pembahasan peraturan desa yang dilakukan oleh BPD dan pemerintah desa merupakan awal dari implementasi fungsi membahas dan menetapkan peraturan desa namun idealnya dari suatu implementasi adalah harus secara tuntas dilakukan, justru tidak dilakukannya implementasi yang tuntas maka tujuan dari implementasi itu tidak tercapai sehingga yang dilami oleh BPD dan pemerinta desa adalah tidak adanya penetapan peraturan desa yang sah. Hal ini dialami oleh BPD dan pemerintah desa Nama.

b. Menampung dan Menyalurkan Aspirasi Masyarakat Desa

Fungsi BPD menampung dan menyalurkan aspirasi masyarakat desa merupakan tugas penting yang harus diperhatikan untuk bagaimana supaya semua keluhan masyarakat dapat tersampaikan kepada pengambil kebijakan dalam hal ini adalah pemerintah desa. Setiap aspirasi yang disampaikan merupakan bentuk atau bagian dari apa yang masyarakat inginkan dan boleh juga dikatakan bagian dari partisipasi masyarakat dalam proses pembangunan desa. Keterlibatan masyarakat dalam proses pembangunan desa lebih ditamakan untuk terciptanya hubungan kerja sama antara pemerintah desa dan masyarakat menuju desa yang aman, nyaman, tentram dan teratur dalam pengelolaan pemerintahan, mengingat pemerintahan yang baik adalah atas dukungan masyarakat yang baik pula.

BPD dalam lingkup Kecamatan Siritaun

Wida Timur telah menjalankan fungsinya menampung dan menyalurkan aspirasi masyarakat desa, selain aspirasi yang disampaikan secara lansung kepada BPD, ada juga metode yang digunakan BPD untuk mendapatkan aspirasi masyarakat desa adalah melakukan pertemuan dengan seluruh masyarakat desa untuk meminta secara lansung aspirasi apa saja yang nantinya disusulkan kepada pemerintah desa. Berbagai macam aspirasi yang diusulkan adalah seperti:

I. Pembangunan jalan setapak.

Letak semua desa dalam Kecamatan Siritaun Wida Timur tidak dilintasi jalan nasional sehingga jalan setapak merupakan prioitas utama dalam pembangunan desa, outcome dari jalan setapak memberikan kemudahan kepada masyarakat yang beraktifitas dalam desa masing-masing baik pada siang hari maupun malam hari.

2. Pembangunan jembatan.

Pembangunan jembatan merupkan langkah penghubung antara mata jalan yang terdapat dalam lingkungan desa sehingga membuat aktifitas masyarakat tidak terganggu.

3. Renovasi rumah warga yang tidak layak huni. Sekian banyak masyarakat dari 10 desa dalam lingkup Kecamatan Siritaun Wida Timur merupakan masyarakat yang berasal dari keluarga tidak mampuh sehingga langkah kebijakan yang dilakukan oleh pemerintah desa dan/atau berdasarkan aspirasi masyarakat desa merupakan langka yang tepat untuk memberikan keringanan kepada masyarakat tertentu sehingga manfaat yang didapatkan adalah hidup sehat dan nyaman. Hidup sehat dan nyaman merupakan 
upaya dalam mendukung program pemerintah dalam bidang kesehatan.

4. Pembangunan talut pemancing pasir.

Minimnya kekayaan alam dalam bentuk pasir dapat ditemukan dibeberapa desa dalam lingkup Kecamatan Siritaun Wida Timur diantaranya adalah Desa Keta, Desa Liantasik, Desa Kuwaos dan Desa Air Nanang. Dari beberapa desa tersebut yang telah membangun program talut pemancing pasing hanyalah Desa Liantasik sedangkan desa lain belum terlaksana. Langkah pembangunan talut pemancing pasing dengan tujuan mengembalikan hasil kekayaan alam yang telah terkuras habis.

5. Pemasangan lampu jalan.

Desa yang gelap dapat menghambat berbagai aktifitas masyarakat dimalam hari tetapi jika desa yang terang dapat memperlancara aktifitas masyarakat dimalam hari kaitannya dengan hal tersebut yaitu sebagaian desa telah menggunakan lampu jalan.

6. Renovasi atap Masjid.

Aspirasi berupa renovasi atap Masjid dilakukan untuk memperbaiki atau mengganti atap Masjid yang tidak layak digunakan. Masjid yang merupakan tempat dimana masyarakat meningkatkan mutu ibadah dan mendekatkan diri kepada Tuhan perlu diperhatikan, aspirasi ini berasa dari masyarakat Desa Aruan Gaur yang telah mendapat perhatian baik dari pemerintah desa setempat.

7. Pembangunan TK-PAUD.

Tingkatan pendidikan di Kecamatan Siritaun Wida Timur diantaranya adalah tingkat SMA/MA, SMP/MTs, dan SD/MI, sedangkan tingkat TKPAUD belum dibangun sehingga mendorong hati nurasi masyarakat untuk menyampaikan aspirasi kepada pemerintah desa lewat BPD, niat baik masyarakat atas pendidikan anak usia dini merupakan bagian dari upaya yang perlu mendapat perhatian pemerintah desa maupun pemerintah daerah untuk peningkatan mutu pendidikan anak-anak desa di Kecamatan Siritaun Wida Timur.

c. Melakukan Pengawasan Kinerja Kepala Desa Pengawasan terhadap kinerja lembaga pemerintah bertujuan untuk memastikan setiap pekerjaan benar-benar dilakukan dan tidak keluar dari apa yang diharapkan, pengawasan masyarakat terhadap semua kinerja yang dilakukan pemerintah dapat melalui BPD, dalam hal pengawasan bahwa BPD dari 10 desa dalam Kecamatan Siritaun Wida Timur telah mengimplementasikan fungsi pengawasan, pengawasan yang dilakukan meliputi pelaksanaan pembangunan desa dan pengawasan terhadap pengelolaan anggaran, dalam hal pengawasan menyangkut anggaran tidak dilakukan oleh BPD Desa Aruan Gaur, Desa Kuwaos, Desa Keta Rumadan, dan Desa Laintasik. Pengawasan kenerja Kepala Desa bukan hanya sekedar mengawasi program fisik yang dibangun oleh Kepala Desa Setempat tetapi pengawasan meliputi semua kinerja yang dilakukan selama menjabat sehingga pengawasan secara keseluruhan yaitu tentang tugas yang diemban. Dalam undang-undang nomor 06 tahun 2014 pasal 26 ayat I menjelaskan bahwa kepala desa bertugas menyelenggarakan pemerintahan desa, melaksanakan pembangunan desa, pembinaan kemasyarakatan desa, dan pemberdayaan masyarakat desa.

Implementasi fungsi pengawasan yang dilakukan BPD dari setiap desa dalam Kecamatan Siritaun Wida Timur hanya mengarah kepada pelaksanaan pembangunan desa dan kegunaan anggaran sedangkan pengawasan terhadap kinerja lain tidak dilakukan. 


\section{KESIMPULAN}

Hasil penelitian menunjukkan bahwa implementasi fungsi Badan Permusyawaratan Desa (BPD) dalam lingkup Kecamatan Siritaun Wida Timur yang telah dilakukan adalah fungsi menampung dan menyalurkan aspirasi masyarakat desa dan fungsi melakukan pengawasan terhadap kenerja kepala desa, sedangkan fungsi membahas dan menyepakati rancangan peraturan desa bersama kepala desa tidak dilakukan. Implementasi menampung dan menyalurkan aspirasi ini adalah benar-benar aspirasi yang disampaikan secara lansung oleh masyaraat saat masyarakat mendatangi BPD maupun disampaikan lewat rapat khusus yang diselenggarakan oleh BPD dengan melibatkan masyarakat, sedangkan implementasi menyangkut pengawasan terhadap kinerja Kepala Desa juga telah dilakukan namun masih terdapat banyak kekurangan yang ditemui, hal ini dikarenakan BDP hanya mengawasi proses pembangunan desa dan penggunaan aggaran sedangkan pengawasan terhadap kinerja lain tidak dilakukan.

Berdasarkan hasil penelitian yang ditemukan maka perlu dilakukan pembenahan untuk menuju kepada implementasi fungsi secara utuh dan sebenarbenarnya implementasi. Untuk itu saran yang perlu peneliti sampaikan adalah:

I. Pemerintah daerah perlu memperhatikan setiap desa yang tergolong dalam Kecamatan Siritaun Wida Timur dengan cara memberikan pelatihan kepada BDP dan Pemerintah Desa tentang fungsi masing-masing, sesuai dengan tujuan penelitian maka pelatihan yang lebih khusus dilakukan adalah kepada BPD berdasarkan undang-undang nomor 06 tahun 2014.

2. Pemerintah Kecamatan Siritaun Wida Timur dalam hal ini adalah Camat perlu melakukan pengontrolan secara maksimal serta menekan semua BPD untuk mengimplementasikan funsinya dengan baik dikarenakan sebagian dari implementasi fungsi tidak berjalan dengan baik bahkan terdapat fungsi yang sama sekali tidak dilakukan.

3. BPD dari 10 desa dalam wilayah Kecamatan Siritaun Wida Timur perlu melakukan pembenahan terhadap fungsi yang dimiliki guna terciptanya kegunaan fungsi dengan baik dan benar.

\section{REFERENSI}

Aggara Sahya 20I4. Kebijakan Publik. CV Pustaka Setia, Bandung.

Agustino, Leo. 2014. Dasar-Dasar Kebijakan Publik. Bandung: CV.Alfabeta

Alyakin Dachi Rahmat 2017. Proses Dan Analisis Kebijakan Kesehatan (Studi Pendekatan Konseptual, CV Budi Utama, Yogyakarta.

B. Sore Uddin dan Sobirin 2017. Kebijakan Publik, CV Sah Media, Makassar.

Elake, Nataniel 20I5. Kebijakan Publik Dalam Pembangunan Masyarakat Pesisir, The Pinisi Press, Yogyakarta.

Fahmi Rijal 2016. Implementasi Undang-Undang Nomor 6 Tahun 2014 Pasal 24 Tentang Penyelenggaraan Pemerintahan Desa di Desa Sungai Mariam Kecamatan Anggana Kabupaten Kutai Kartanegara, ejournal.ip.fisip-unmul.ac.id 2016, 4 (3): I023-I 032 ISSN 2477-2458.

Riant Nugroho. 2013. Metode Penelitian Kebijakan. Yogyakarta: Pustaka Pelajar.

Subarsono. 2013. Analisis Kebijakan Publik, Konsep, Teori dan Aplikasi. Yogyakarta: Pustaka Pelajar.

Taufiqurakhman 20I4. Kebijakan Publik, Pendelegasian Tanggungjawab Negara Kepada Presiden Selaku Penyelenggara Pemerintahan. Fakultas Ilmu Soaial dan Ilmu Politik Universitas Moestopo Beragama (Pers). Senayan Jakarta Pusat.

Tahir Arifin 2015. Kebijakan Publik Dan Transparansi Penyelenggaraan Pemerintahan Daerah, Alfabeta, Bandung.

Undang-undang nomor 06 tahun 2014 tentang desa

Wahab, Solichin Abdul. 20I5. Analisis Kebijaksanaan Dari Formulasi ke Penyusunan Model-Model Implementasi Kebijakan Publik. Malang : Bumi Aksara. 